\title{
Combined strategy for the precipitation of heavy metals and biodegradation of petroleum in industrial wastewaters
}

\author{
R.M. Pérez ${ }^{\mathrm{a}}$, G. Cabrera ${ }^{\mathrm{b}, *}$, J.M. Gómez ${ }^{\mathrm{b}}$, A. Ábalos $^{\mathrm{a}}{ }^{\text {, D. Cantero }}{ }^{\mathrm{b}}$ \\ a Study Centre of Industrial Biotechnology, Faculty of Natural Sciences, University of East Santiago of Cuba, CP 90500, Cuba \\ b Department of Chemical Engineering and Food Technology, Faculty of Sciences, University of Cadiz, Campus Rio San Pedro, 11510 Puerto Real, Cádiz, Spain
}

\section{A R T I C L E I N F O}

\section{Article history:}

Received 22 December 2009

Received in revised form 30 June 2010

Accepted 1 July 2010

Available online 27 July 2010

\section{Keywords:}

Pseudomonas aeruginosa

Desulfovibrio $s p$.

Biodegradation

Heavy metal

Petroleum

\begin{abstract}
A B S T R A C T
The precipitation of chromium(III), copper(II), manganese(II) and zinc(II) by biogenic hydrogen sulfide generated by sulfate-reducing bacteria, Desulfovibrio sp., and the degradation of total petroleum hydrocarbons (TPH) in the presence of heavy metal by Pseudomonas aeruginosa AT18 have been carried out. An anaerobic stirred tank reactor was used to generate hydrogen sulfide with Desulfovibrio sp. culture and the precipitation of more than $95 \%$ of each metal was achieved in $24 \mathrm{~h}$ (metal solutions contained: 60 , 49, 50 and $80 \mathrm{mg} \mathrm{L}^{-1}$ of chromium, copper, manganese and zinc sulfates). A stirred tank reactor with $P$. aeruginosa AT18, in the presence of the heavy metal solution and $2 \%(\mathrm{v} / \mathrm{v})$ of petroleum, led to the degradation of $60 \%$ of the total petroleum hydrocarbons and the removal of $\mathrm{Cr}$ (III) $99 \%, \mathrm{Cu}$ (II) $93 \%, \mathrm{Zn}$ (II) $46 \%$ and $\mathrm{Mn}(\mathrm{II}) 88 \%$ in the medium through biosorption phenomena. These results enabled the development of an integrated system in which the two processes were combined. The overall aim of the study was achieved, with $84 \%$ of TPH degraded and all of the metals completely removed. Work is currently underway aimed at improving this system (decrease in operation time, culture of $P$. aeruginos $a$ in anaerobic conditions) in an effort to apply this process in the bioremediation of natural media contaminated with heavy metals and petroleum.
\end{abstract}

(c) 2010 Elsevier B.V. All rights reserved.

\section{Introduction}

Organic pollutants and heavy metals are often present together in industrial wastewaters and contaminated sites from mine areas $[1,2]$. Many of these contaminants are toxic, mutagenic and carcinogenic, and they are persistent in the environment-thus presenting a significant hazard to ecosystems and human health $[3,4]$. The hazardous nature and persistence of these materials in the environment means that it would take decades to clean up such sites. As a result, the development of remediation technologies for these types of contamination is urgently needed.

The remediation of sites co-contaminated with organic (petroleum, chlorinated solvents, pesticides, herbicides) and metal pollutants is a complex problem, as both kinds of compounds usually require treatment with a different methodology.

Heavy metals cannot be biodegraded and, in mining and industrial areas, they are often present in a soluble form such as sulfates, which are easily accessible to the natural environment. The best way to reduce the mobility of heavy metals is to transform them into insoluble compounds such as sulfides, which are more stable

\footnotetext{
* Corresponding author. Tel.: +34 956016554; fax: +34 956016411.

E-mail addresses: rmaria@cebi.uo.edu.cu (R.M. Pérez), gema.cabrera@uca.es (G. Cabrera).
}

forms. Sulfate-reducing bacteria (SRB), under anaerobic conditions, oxidize simple organic compounds (such as acetic acid and lactic acid) by utilizing sulfate as an electron acceptor and generate hydrogen sulfide. Hydrogen sulfide reacts with heavy metal ions to form insoluble metal sulfides that can be easily separated from solution [5-8].

The potential advantages of metal sulfide precipitation include the production of lower sludge volumes and products with lower solubility as compared to hydroxide precipitation [9]. In addition, valuable metals can be recovered from metal sulfide sludges [10].

Biological sulfate reduction has been studied in various reactor designs, including the continuous stirred tank reactor (CSTR) [11], anaerobic contact process [12], anaerobic filter [13-15], up-flow anaerobic sludge blanket reactor (UASB) $[5,10,16]$, hybrid reactor [6,17] and fluidized-bed reactor (FBR) [18].

Petroleum contains thousands of individual hydrocarbons and related compounds. Numerous microorganisms that are capable of degrading petroleum components have been isolated. Given the complexity of oil products, a combination of bacterial strains with broad enzymatic capabilities will be required to achieve extensive degradation. However, most of the crude oil degradation studies reported in the literature have been carried out with single or mixed bacterial strains isolated because of their ability to grow in mineral media with crude oil as the only carbon source. [19,20]. Pseudomonas aeruginosa belongs to this group of microorganisms. It is 
found in soil, water, and most man-made environments throughout the world [21]. It is a gram-negative, aerobic, rod-shaped bacterium with unipolar motility [22]. In a previous study [23] we investigated the total petroleum hydrocarbons (TPH) biodegradation of crude oil with $P$. aeruginosa AT18 isolated from contaminated soil of a petroleum refinery (Santiago de Cuba). The strain was grown on kerosene (C12-C14), lubricant oil (C18-C40), toluene (alkylbenzene), naphthalene (polyaromatic) and evidences were found for the presence of alk, tol, nah genes.

Data from both aerobic and anaerobic systems demonstrate that the metabolism of organic compounds can be reduced by metal toxicity [24-26]. This fact leads one to consider an integrated system that involves biological metal precipitation and the subsequent biodegradation of petroleum. Integrated systems can prove advantageous from operational, economic and efficiency points of view.

The work described here was focused on the precipitation process of chromium(III), copper(II), manganese(II) and zinc(II) by biogenic hydrogen sulfide generated by sulfate-reducing bacteria, Desulfovibrio sp., and TPH degradation by P. aeruginosa AT18. The biological processes were carried out in two ways. Firstly, metal bioprecipitation and petroleum biodegradation systems were studied separately, with the aim of evaluating the individual capacity of each process. Secondly, the bioprecipitation and biodegradation processes were combined in a two-stage system, which is referred to as the 'integrated system'.

\section{Experimental}

\subsection{Bacterial strain and culture conditions}

\subsubsection{Pseudomonas aeruginosa strain}

Strain AT18 (CCCEBI 1044) was isolated from contaminated soil samples from the crude oil refinery in Santiago de Cuba (Cuba). Taxonomical characterization of strain AT18 BLAST and FASTA systems showed a similarity of $99.9 \%$ to $P$. aeruginosa AL98 (AJ249451), a degrader of natural rubber [27], and $99.9 \%$ to $P$. aeruginosa $42 \mathrm{~A} 2$ NCBIMB 40045 (AJ309500). A high RDP match was found (0.90) in both cases [28]. The strain was maintained by overnight cultures and preserved in criovials at $-20^{\circ} \mathrm{C}$. P. aeruginosa AT18 was grown in a mineral medium with the following composition $\left(\mathrm{g} \mathrm{L}^{-1}\right)$ : $\mathrm{NaNO}_{3}, 4.64 ; \mathrm{K}_{2} \mathrm{HPO}_{4} / \mathrm{KH}_{2} \mathrm{PO}_{4}$ (ratio $2: 1$ ), $1 ; \mathrm{FeSO}_{4} \cdot 7 \mathrm{H}_{2} \mathrm{O}, 0.0074$; $\mathrm{CaCl}_{2}, 0.01 ; \mathrm{KCl}, 0.10 ; \mathrm{MgSO}_{4} \cdot 7 \mathrm{H}_{2} \mathrm{O}, 0.50$; yeast extract, 0.10 and supplemented with $0.05 \mathrm{~mL} \mathrm{~L}^{-1}$ of a trace mineral solution $\left[\left(\mathrm{g} \mathrm{L}^{-1}\right)\right.$ : $\mathrm{H}_{3} \mathrm{BO}_{3}, 0.26 ; \mathrm{CuSO}_{4} \cdot 5 \mathrm{H}_{2} \mathrm{O}, 0.50 ; \mathrm{MnSO}_{4} \cdot \mathrm{H}_{2} \mathrm{O}, 0.50 ; \mathrm{MoNa}_{2} \mathrm{O}_{4} \cdot 2 \mathrm{H}_{2} \mathrm{O}$, $0.06 ; \mathrm{ZnSO}_{4} \cdot 7 \mathrm{H}_{2} \mathrm{O}, 0.70$ ] and $0.20 \mathrm{~g} \mathrm{~L}^{-1}$ crude oil as the carbon source. The strain was incubated at $30^{\circ} \mathrm{C}$ and $200 \mathrm{rpm}$ in a rotary shaker.

\subsubsection{Sulfate-reducing bacteria (SRB)}

The sulfate-reducing bacteria used in this study were Desulfovibrio sp. (ATCC 49975). These cultures were maintained in modified Postgate B medium [ $\left(\mathrm{g} \mathrm{L}^{-1}\right): \mathrm{KH}_{2} \mathrm{PO}_{4}, 0.5 ; \mathrm{NH}_{4} \mathrm{Cl}, 1.0 ; \mathrm{CaSO}_{4} \cdot 2$ $\mathrm{H}_{2} \mathrm{O}, 1.26$; $\mathrm{MgSO}_{4} \cdot 7 \mathrm{H}_{2} \mathrm{O}$, 2.0; sodium lactate 3.5; yeast extract, 1.0; ascorbic acid, 0.1; thioglycolic acid, 0.1 and $\mathrm{FeSO}_{4} \cdot 7 \mathrm{H}_{2} \mathrm{O}$, 0.5] [29]. $10 \mathrm{~mL}$ glass bottles containing Postgate $\mathrm{B}$ medium were sterilized at $121{ }^{\circ} \mathrm{C}$ during $20 \mathrm{~min}$ and allowed to cool down to room temperature. $10 \%(\mathrm{v} / \mathrm{v})$ of inoculum was then added to the bottles. Vessels were sealed immediately in order to provide the anaerobic conditions that were promoted by reducing compounds (ascorbic acid, thioglycolic acid). Cultures were incubated at $30^{\circ} \mathrm{C}$ for $24 \mathrm{~h}$. The formation of ferrous sulfide, which was detected as a black precipitate, indicated that bacterial growth had taken place and the bottles were then stored at $4{ }^{\circ} \mathrm{C}$.

For metal precipitation studies, sulfate-reducing bacteria were previously grown in nutrient Postgate $C$ medium $\left[\left(\mathrm{g} \mathrm{L}^{-1}\right)\right.$ :
$\mathrm{Na}_{2} \mathrm{SO}_{4}$, 4.5; yeast extract, 1 sodium lactate, $6 ; \mathrm{CaCl}_{2} \cdot 6 \mathrm{H}_{2} \mathrm{O}, 0.06$; $\mathrm{MgSO}_{4} \cdot 7 \mathrm{H}_{2} \mathrm{O}, 0.06$ and $\mathrm{NH}_{4} \mathrm{Cl} 1.0$ ] and petroleum (2\%,v/v) as appropriate. The $\mathrm{pH}$ of the medium was adjusted to $7.5 \pm 0.05$ and it was sterilized at $121^{\circ} \mathrm{C}$ during $20 \mathrm{~min}$. Nutrient medium was dispensed into $50 \mathrm{~mL}$ glass bottles with $10 \%(\mathrm{v} / \mathrm{v})$ of inoculum.

\subsection{Precipitation of heavy metals with hydrogen sulfide generated by Desulfovibrio sp.}

The precipitation of metal ions was studied in a system composed of a Desulfovibrio sp. anaerobic stirred reactor, named D.sp. reactor, in which culture growth was carried out, and a precipitation reactor, in which biogenic hydrogen sulfide, generated by Desulfovibrio sp., came into contact with the heavy metal solution.

\subsubsection{D.sp. reactor}

A culture of Desulfovibrio sp., previously grown in Postgate C medium in the exponential growth phase, was added $(10 \%, \mathrm{v} / \mathrm{v})$ to a glass vessel (working volume $800 \mathrm{~mL}$ ) with Postgate $C$ medium. This reactor was provided with temperature and $\mathrm{pH}$ sensors and a nitrogen gas inlet to maintain the anoxic conditions necessary for anaerobic bacterial growing (Fig. 1a). The system was maintained for $96 \mathrm{~h}$ in batch operation mode in order to obtain an active bacterial population and then the reactor started to work in continuous operation mode. Samples were taken every $12 \mathrm{~h}$ during the batch step and every $24 \mathrm{~h}$ during the continuous step $(120 \mathrm{~h}, 8.3 \mathrm{~mL} / \mathrm{h})$. Each sample was analyzed for cell growth, $\mathrm{pH}$ and concentration of sulfate and sulfide.

\subsubsection{Precipitation reactor}

In order to determine the capacity for the precipitation of metal ions by biogenic hydrogen sulfide, a solution $(100 \mathrm{~mL})$ with sulfates of $\mathrm{Cr}(\mathrm{III}), \mathrm{Cu}(\mathrm{II}), \mathrm{Mn}(\mathrm{II})$ and $\mathrm{Zn}(\mathrm{II})$ was prepared to give concentrations of $60,49,50$, and $80 \mathrm{mg} \mathrm{L}^{-1}$, respectively. This solution was placed in a conical vessel and volume of hydrogen sulfide from the bioreactor was added daily to the solution of metal ions. This process was monitored by measuring the $\mathrm{pH}$ and metal concentration in solution.

\subsection{Degradation of petroleum in the presence of $\mathrm{Cr}(\mathrm{III}), \mathrm{Cu}(\mathrm{II})$,} $\mathrm{Mn}$ (II) and $\mathrm{Zn}$ (II) by Pseudomonas aeruginosa AT18 in the aerobic stirred tank reactor

The degradation of TPH by P. aeruginosa AT18 in the presence of metals was carried out in a $1 \mathrm{~L}$ aerobic stirred tank reactor, which is referred to as a P.a. reactor (Fig. $1 \mathrm{~b}$ ). The reactor was prepared with $590 \mathrm{~mL}$ of mineral medium supplemented with a metal ion solution [( $\left.\mathrm{mg} \mathrm{L}^{-1}\right): \mathrm{Cr}_{2}\left(\mathrm{SO}_{4}\right)_{3}, 60 ; \mathrm{CuSO}_{4}, 49 ; \mathrm{MnSO}_{4}, 50 ; \mathrm{ZnSO}_{4}$, 80 ] with $2 \%(\mathrm{v} / \mathrm{v})$ of petroleum and $2 \%(\mathrm{v} / \mathrm{v})$ of a cellular culture in the exponential growth phase. The reactor was provided with an air inlet to allow aerobic conditions for cellular growth and also had temperature and $\mathrm{pH}$ sensors. The system was incubated at $30^{\circ} \mathrm{C}$ and $150 \mathrm{rpm}$ and was maintained in fed-batch operation mode for $360 \mathrm{~h}$.

A sample was removed every $24 \mathrm{~h}$ until the culture reached a stationary growth phase. After this period sampling was carried out every $72 \mathrm{~h}$ and analysis was performed to determine the cell growth, $\mathrm{pH}$ and concentration of metals. The concentration of hydrocarbon was determined at the end of the process.

\subsection{Integrated system for heavy metal precipitation/petroleum degradation}

Integration of the heavy metal precipitation and TPH biodegradation processes was carried out in the experimental system shown in Fig. 1c. D.sp. and P.a. reactors were 
(a)

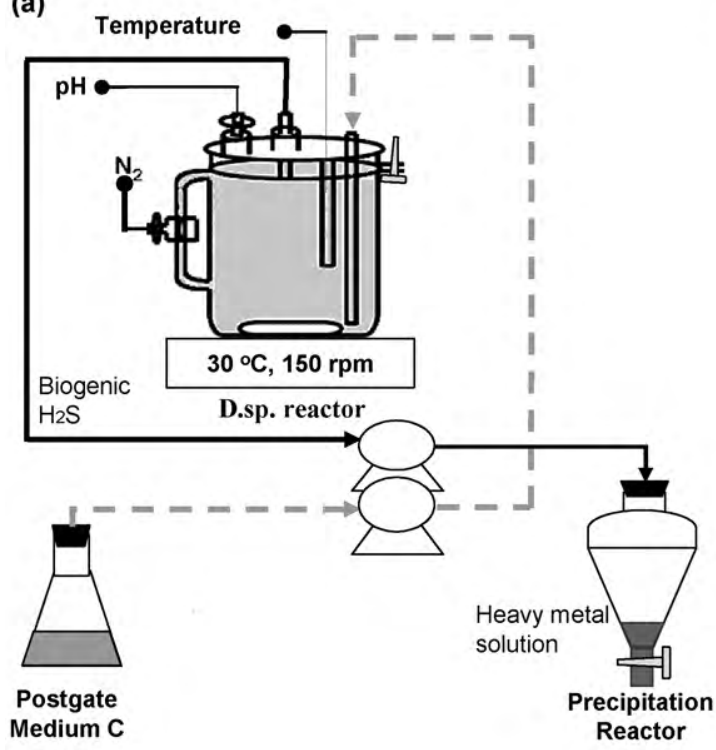

(b)

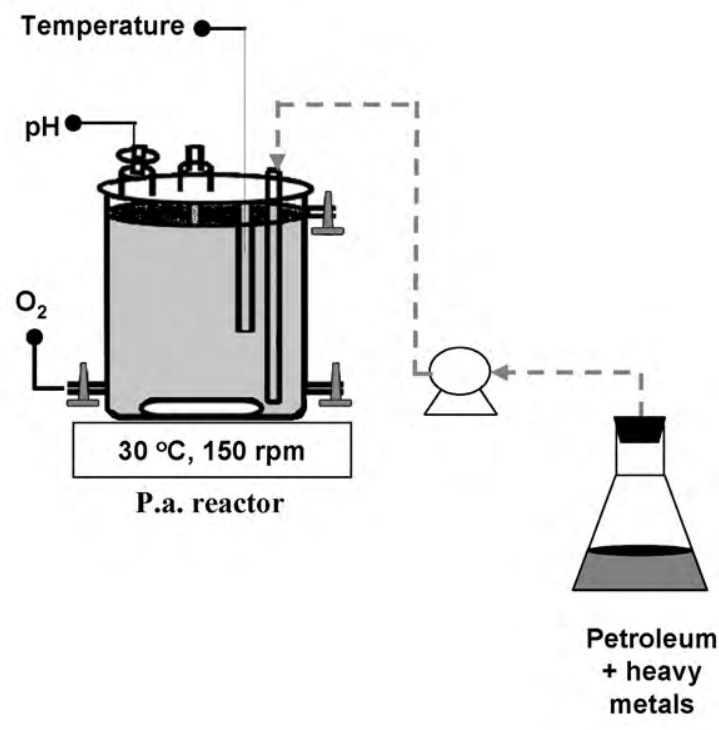

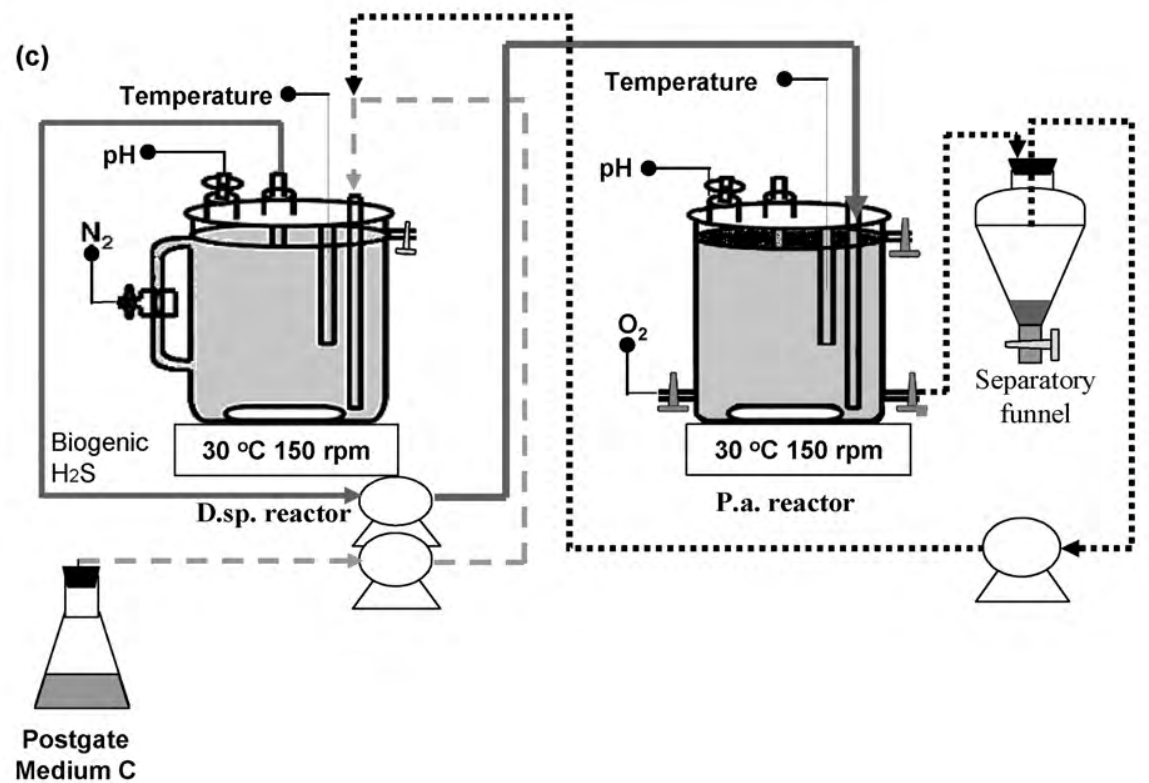

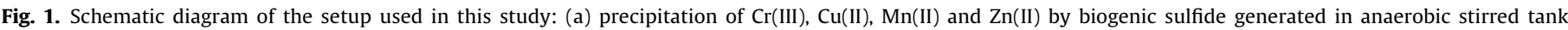

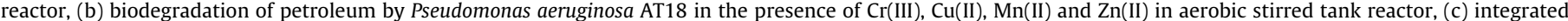
precipitation-biodegradation system in which P.a. reactor was supplemented with heavy metals and petroleum.

prepared with similar conditions of media, temperature and agitation rate as corresponding experiments described above.

The effluent (hydrogen sulfide) from the D.sp. reactor was added to the P.a. reactor $(8.3 \mathrm{~mL} / \mathrm{h})$ and this was supplemented with petroleum (2\%) and a heavy metal solution (same concentrations as in the individual experiments). The effluent of the second reactor was placed in a separatory funnel in order to facilitate the decantation of metal precipitates. The supernatant of this funnel was recirculated to the D.sp. reactor in conjunction with fresh Postgate $\mathrm{C}$ medium, in order to improve the removal of contaminants.

In this integrated process, samples from the D.sp. reactor were analyzed for biomass, $\mathrm{pH}$, sulfide and sulfate concentrations and, for the P.a. reactor, biomass, $\mathrm{pH}$, metal and petroleum concentrations were measured.

\subsection{Analytical methods}

Free bacterial population was represented by counting cells in a Neubauer chamber using an optical microscope (Olympus BH-2). The results are reported in Mcell $\mathrm{mL}^{-1}$.

Sulfate concentration was measured by a turbidimetric method [30]. Samples were filtered $(0.22 \mu \mathrm{m}$ pore size $)$ to avoid the interference of biomass and heavy metal precipitates in the measurement.

Sulfide concentration was determined by the colorimetric methylene blue method [30].

Dissolved metal concentrations were determined by inductively coupled plasma atomic emission spectroscopy (ICP-AES, Iris Intrepid-Thermo-elemental Series 11393, Model 14425501). The filtered samples were acidified $\left(2 \mathrm{~N} \mathrm{HNO}_{3}\right)$ and stored at $4{ }^{\circ} \mathrm{C}$ until the measurement was performed [30]. 
$\mathrm{pH}$ values were registered using a CRISON $\mathrm{pH}$ meter provided with an Ag electrode.

\subsubsection{Crude oil analysis}

The residual crude oil from cultures and controls was extracted with dichloromethane on duplicate samples. Prior to extraction, a-androstane was added to each flask as an internal standard. The extracts were dried over $\mathrm{Na}_{2} \mathrm{SO}_{4}$, concentrated under vacuum (rotary evaporator), and dried again under a gentle nitrogen stream. Analysis was as follows:

(i) Column chromatography: All the extracts were fractionated [31]. Each extract was resuspended in $1 \mathrm{~mL}$ of dichloromethane and loaded onto a glass column (30.1 cm i.d.) filled with $10 \mathrm{~g}$ of $5 \%$ water-deactivated alumina ( $70-230$ mesh, Merck). The total petroleum hydrocarbon fraction (TPH) was obtained by eluting with $100 \mathrm{~mL}$ of dichloromethane.

(ii) GC-FID: Biodegradation of saturated compounds of TPH fractions was verified by gas chromatography with a flame ionization detector (GC-FID). A Thermoquest Trace 2000 gas chromatograph was used. Compounds were separated on a DB5 capillary column ( $25 \mathrm{~m}$ by $0.32 \mathrm{~mm}$ [i.d.] $0.25-\mu \mathrm{m}$ film thickness). The column temperature was held at $35^{\circ} \mathrm{C}$ for $2 \mathrm{~min}$ and then programmed to $310^{\circ} \mathrm{C}$ at a rate of $4{ }^{\circ} \mathrm{C}$ min. This final temperature was held for $10 \mathrm{~min}$. The detector and inlet temperature were set at 320 and $290^{\circ} \mathrm{C}$, respectively. The helium gas flow was $1.1 \mathrm{~mL} \mathrm{~min}^{-1}$ and the injection volume was $1 \mathrm{~mL}$.

(iii) GC-MS-SIM: Biodegradation of the aromatic compounds in TPH fractions was verified by gas chromatography coupled to a mass spectrometer operating in selected ion monitoring mode (GC-MS-SIM). Gas chromatography/mass spectrometry analyses were performed with a Hewlett Packard 5890 series II gas chromatograph with a 5989A mass selective detector. Compounds were separated on an HP- 5 capillary column ( $25 \mathrm{~m}$ by $0.32 \mathrm{~mm}$ [i.d.]) with $0.25-\mu \mathrm{m}$ film thickness and helium was used as the carrier gas ( $10 \mathrm{psi})$. The column temperature was held at $35^{\circ} \mathrm{C}$ for $2 \mathrm{~min}$ and then programmed to $310^{\circ} \mathrm{C}$ at a rate of $4{ }^{\circ} \mathrm{C} \mathrm{min}^{-1}$. This final temperature was held for $10 \mathrm{~min}$. Injector and transfer line temperatures were set at $280^{\circ} \mathrm{C}$ and the analyzer was set at $300^{\circ} \mathrm{C}$. The injection was in splitless mode with the split valve kept closed for $30 \mathrm{~s}$. The targets for analysis were naphthalene, phenanthrene and their $\mathrm{C} 1-\mathrm{C} 4$ alkyl derivatives; fluorene, dibenzothiophene and their $\mathrm{C} 1-\mathrm{C} 3$ alkyl derivatives; and fluoranthene, pyrene and chrysene. The biodegradation of each analyte was followed by obtaining the corresponding chromatogram. The comparison of peak areas of the compounds in cultures and in controls assays allows determined the level of biodegradation.

\section{Results and discussion}

\subsection{Precipitation of heavy metals by Desulfovibrio sp. in an anaerobic stirred tank reactor}

Prior to this study, several discontinuous experiments were carried out in order to determine the tolerance of Desulfovibrio $s p$. to several heavy metal ions [ $\mathrm{Cr}(\mathrm{III}), \mathrm{Cu}(\mathrm{II}), \mathrm{Mn}(\mathrm{II}), \mathrm{Ni}(\mathrm{II})$ and $\mathrm{Zn}(\mathrm{II})][32]$. The capacity of these bacteria to precipitate these ions as sulfides or oxides was also evaluated. The results obtained showed that cellular growth - and thus the precipitation capacity - was affected on increasing the metal concentration. For this reason, the D.sp. reactor was designed to be separate from the precipitation reactor in order to avoid the influence of heavy metals on bacterial activity and subsequently on the efficiency of the precipitation step.
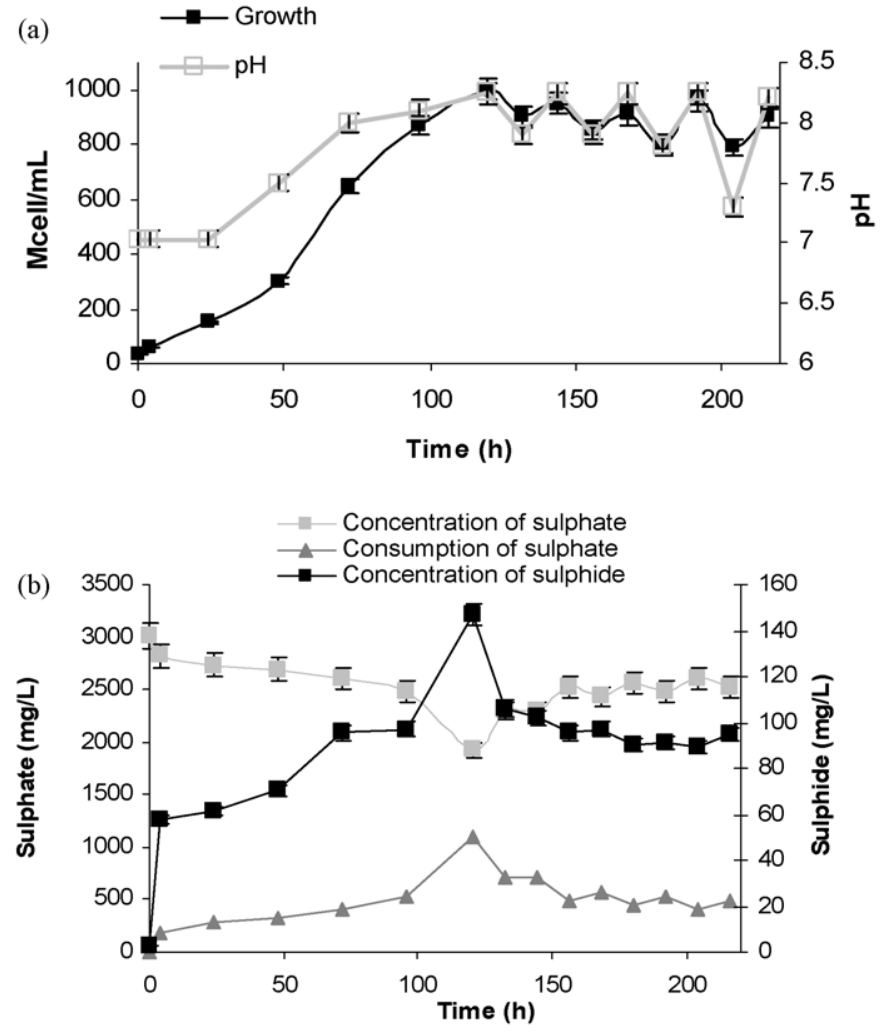

Fig. 2. Kinetic of anaerobic reactor: (a) growth of Desulfovibrio sp. and $\mathrm{pH}$, and (b) formation of sulfide and variation of sulfate in solution.

With the purpose of obtaining biogenic hydrogen sulfide, Desulfovibrio $s p$. was cultivated in a stirred tank reactor under anaerobic conditions. Initially the system was maintained in discontinuous operation mode during $96 \mathrm{~h}$ (Fig. 2a) to reach the exponential growth phase $\left(\mu=1 \times 10^{-1} \mathrm{~h}^{-1}\right)$. After this period, the reactor was fed in semi-continuous mode with Postgate $\mathrm{C}$ medium $\left(8.3 \mathrm{~mL} \mathrm{~h}^{-1}\right)$ and the effluent from this reactor was added to the precipitation reactor. In this step, the bacterial population was in the range $800-1000$ Mcell mL $^{-1}$ and the sulfate concentration was around 1.9-2.5 g L $\mathrm{L}^{-1}$ (Fig. 2b). Daily sulfate uptake was $217.8 \mathrm{mg} \mathrm{L}^{-1}$. The maximum sulfide concentration, $146.88 \mathrm{mg} \mathrm{L}^{-1}$, was reached at $120 \mathrm{~h}$, in accordance with the maximum value of the bacterial population (1000 Mcell $\mathrm{mL}^{-1}$ ).

The precipitation reactor, containing a solution $(100 \mathrm{~mL})$ of several heavy metals, was fed with the solution from the D.sp. reactor, which was rich in hydrogen sulfide. The addition of this stream caused the precipitation of heavy metals as the insoluble forms-presumably $\mathrm{Cr}_{2} \mathrm{O}_{3}, \mathrm{CuS}$, MnS and $\mathrm{ZnS}$, the most common forms in which these heavy metal ions are present in reducing conditions. The concentrations of heavy metal ions in solution were measured in order to determine the level of precipitation of each metal. After $24 \mathrm{~h}$ the precipitation levels were $98 \%$ $\mathrm{Cr}(\mathrm{III}), 99 \% \mathrm{Cu}(\mathrm{II}), 96.5 \% \mathrm{Mn}(\mathrm{II})$ and $99.5 \% \mathrm{Zn}(\mathrm{II})$. As a result, the system was operated by loads; the reactor was supplemented with the metal solution daily and the volume of hydrogen sulfide solution generated in D.sp reactor. The order in which the maximum precipitation levels of each metal were achieved was: $\mathrm{Cu}(\mathrm{II}), \mathrm{Cr}(\mathrm{III}), \mathrm{Zn}(\mathrm{II})$ and $\mathrm{Mn}$ (II) (data not shown). This order can be explained by considering the $\mathrm{p} K_{\mathrm{ps}}$ values of the precipitated compounds: $35.9(\mathrm{CuS})>28.52\left(\mathrm{Cr}_{2} \mathrm{O}_{3}\right)>24.53(\mathrm{ZnS})>13.33(\mathrm{MnS})$ [33]. The results obtained justify the separation of the process into two stages: biological production of $\mathrm{H}_{2} \mathrm{~S}$ and precipitation. In this case, although the added metal solution contained higher concentrations of metal ions, a higher level of precipitation was obtained 
in comparison to the discontinuous experiments carried out on the laboratory scale in our previous study [32]. This difference is due to the fact that bacterial inhibition by heavy metals was avoided.

\subsection{Degradation of petroleum by Pseudomonas aeruginosa AT18 in an aerobic stirred tank reactor}

Prior to this study, several discontinuous experiments were carried out in order to determine the capacity of $P$. aeruginosa to degrade petroleum in the presence of the heavy metals $\mathrm{Cr}(\mathrm{III})$, $\mathrm{Cu}(\mathrm{II}), \mathrm{Mn}(\mathrm{II}), \mathrm{Ni}(\mathrm{II})$ and $\mathrm{Zn}(\mathrm{II})$. A level of TPH degradation of $60 \%$ was reached [23]. The capacity of these bacteria to adsorb heavy metals was also evaluated [35]. Petroleum biodegradation was carried out in a reactor inoculated with $P$. aeruginosa AT18 supplemented with a solution of petroleum and heavy metals. The evolution of bacterial growth showed two different steps in the exponential growth phase (Fig. 3). The first step, between 24 and $120 \mathrm{~h}$, showed a fast growth rate $\left(2.8 \times 10^{-2} \mathrm{~h}^{-1}\right)$ and the second step, between 144 and $216 \mathrm{~h}$, showed a decrease in the growth rate $\left(9.6 \times 10^{-3} \mathrm{~h}^{-1}\right)$. This behavior can be explained by considering the level of complexity of different fractions of petroleum.

In the first stage, the bacteria degrade the simplest fraction of crude petroleum (n-alkanes, short chain paraffins) which undergoes consecutive oxidation to $\beta$-oxidation [20]. Aliphatic hydrocarbons are degraded at the greatest rate, but the key step is oxidation of the molecule to increase the solubility. Most of the microorganisms degrade $\mathrm{n}$-alkanes to the corresponding terminal alcohol by means of monooxygenases, which hydrolyze the terminal carbon through the participation of an oxygen molecule [35]. This fact explains why the growth rate in the first stage is three times higher than that in the second exponential phase, probably

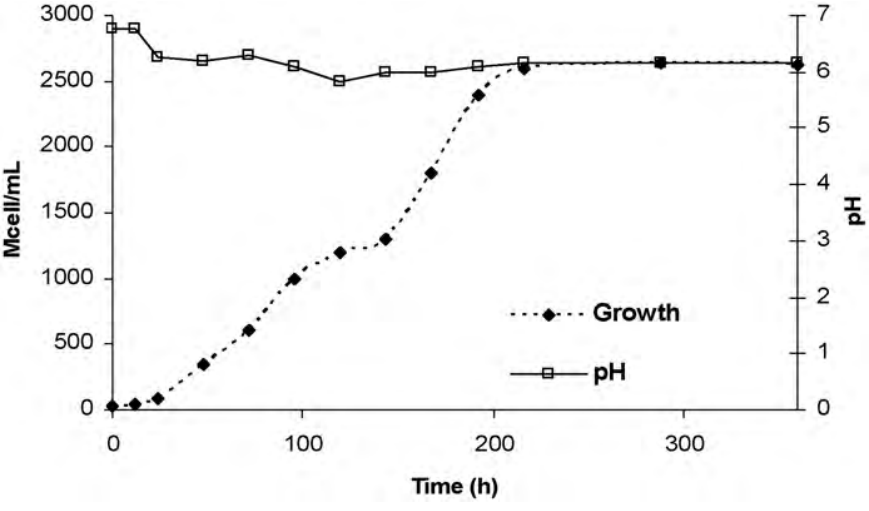

Fig. 3. Pseudomonas aeruginosa AT18 growth on petroleum in the presence of heavy metals $\mathrm{Cr}(\mathrm{III}), \mathrm{Cu}(\mathrm{II}), \mathrm{Mn}(\mathrm{II})$ and $\mathrm{Zn}(\mathrm{II})$

because heavy fractions (isoprenoid, alkanes with more than 20 carbon atoms, cycloalkanes and aromatics) can be degraded.

In this experiment, $P$. aeruginosa AT18 was able to degrade $60 \%$ of the petroleum (Mesa30/Puerto Escondido) in the aerobic reactor (Fig. 4a). This is a significant quantity when compared to that reported by Morán et al. (2000), who observed that Bacillus subtilis 09 was capable of biodegrading hydrocarbons by 35\% [35].

The GC-MS study of the total organic extract (Fig. 4b and c) showed that $P$. aeruginosa AT18 eliminated the $\mathrm{n}$-alkanes and the ramified alkanes completely - these components represent the majority of the compounds resolved by GC-MS for the total organic extract - and the degradation was complete after 15 days of incubation.

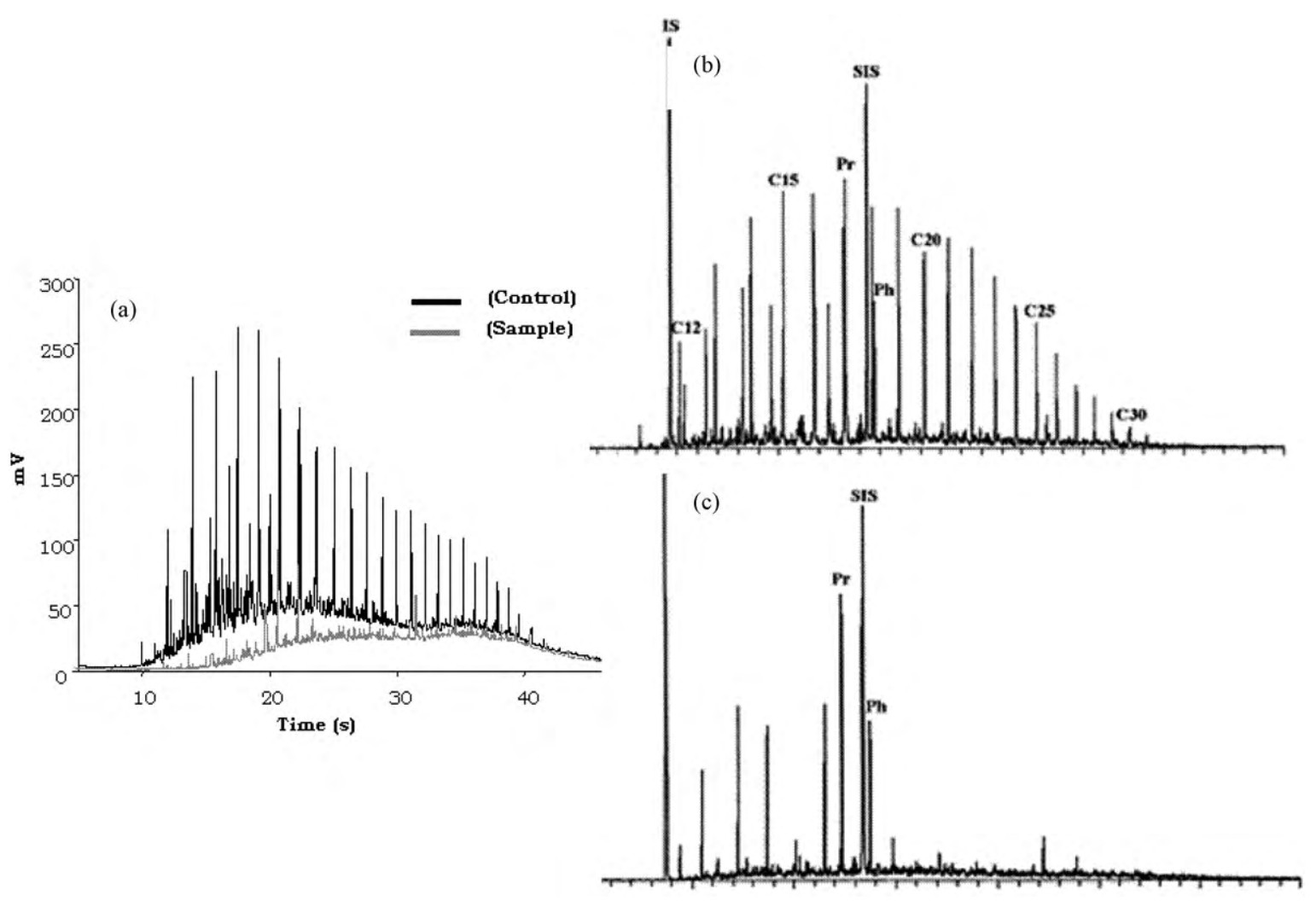

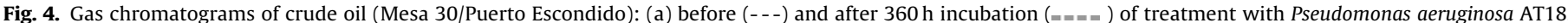

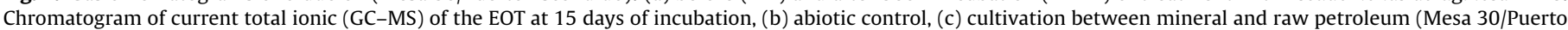

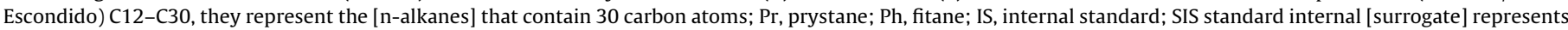
the number of atom present in the group of HAPs alkylic. 


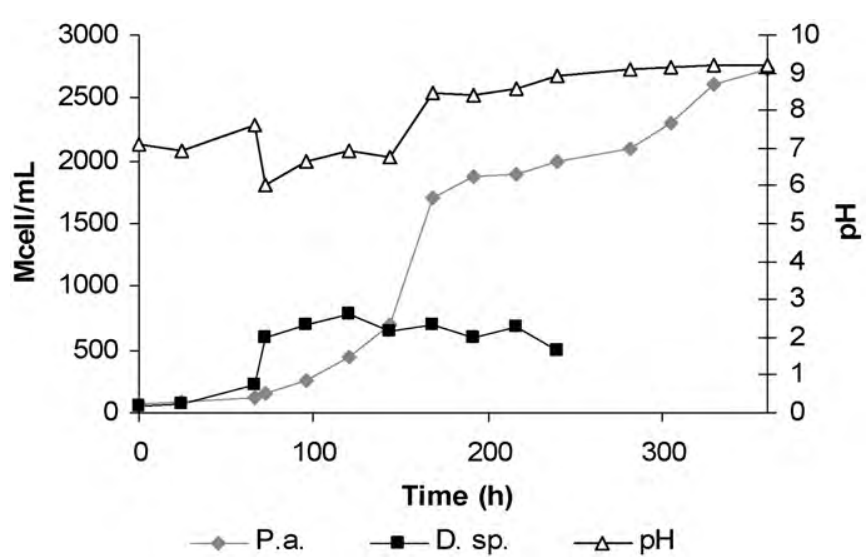

Fig. 5. Growth of Pseudomonas aeruginosa AT18 and Desulfovibrio sp. in each reactor of the integrated system and $\mathrm{pH}$ in the effluent of P.a. reactor.

P. aeruginosa AT18 achieved a considerable level of degradation of the PAHs (polycyclic aromatic hydrocarbons) with two and even three rings (data not shown) as evidenced by chromatograms of ions selections for the PAH. Naphthalene was degraded further to the limit of detection $\left(0.5 \mu \mathrm{g} \mathrm{mL}^{-1}\right)$.

Moreover, during the degradation process $P$. aeruginosa AT18 adsorbed the heavy metals present in solution by the following levels: $\mathrm{Cr}$ (III) 99\%, Cu(II) 93\%, $\mathrm{Zn}$ (II) $46 \%$ and $\mathrm{Mn}$ (II) $88 \%$. These results suggest that is possible the use of these bacteria in the treatment of waters contaminated with petroleum and heavy metals.

\subsection{Integration of processes}

Taking into account the results obtained and the characteristics of wastes in mining and industrial areas, the purpose of our study was the integration of the two processes to assess their potential for the total removal of contaminants in a single process. The sulfatereducing bacteria reactor worked under similar conditions as in the individual experiment and, once the stationary phase was achieved (96 h, Fig. 5), the reactor started to operate in continuous operation mode $(8.3 \mathrm{~mL} / \mathrm{h})$. The effluent from this reactor - a medium rich in hydrogen sulfide (near to $2 \mathrm{~g} \mathrm{~L}^{-1}$ ) - was then introduced into a P.a. reactor that contained the solution of heavy metals and petroleum. The effluent from the latter reactor was introduced into a separatory funnel and the supernatant was again fed into the D.sp. reactor with fresh Postgate $C$ medium. This step caused a slight decrease in the bacterial population in the D.sp. reactor, a change that could be caused by the addition of heavy metals, petroleum or even oxygen into the recirculating stream. It is well known that sulfate-reducing bacteria are strictly anaerobic and, as a result, biological activity

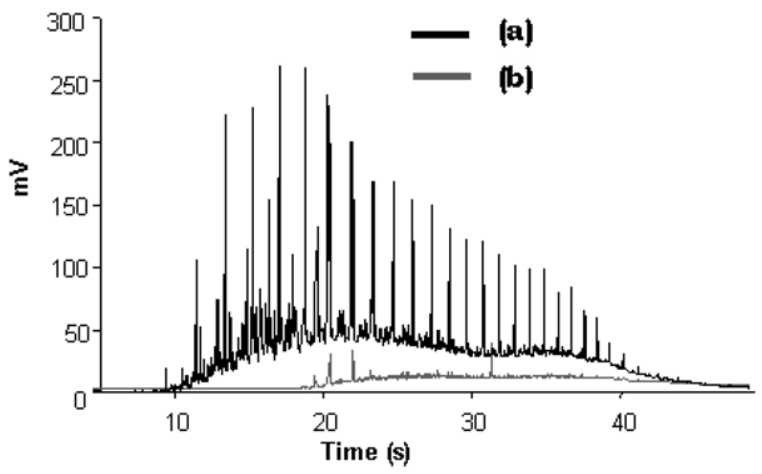

Fig. 7. Gas chromatogram of crude oil Mesa 30/Puerto Escondido (a) before and (b) after $360 \mathrm{~h}$ of treatment with Pseudomonas aeruginosa AT18. Integrated system.

can be affected by the presence of oxygen in the medium. With regard to growth in the P.a. reactor (Fig. 5) the characteristic diauxic growth was observed but the addition of hydrogen sulfide from the D.sp. reactor extended the first exponential growth phase from 4 to 7 days and the growth rate suffered a decrease $\left(2.1 \times 10^{-2} \mathrm{~h}^{-1}\right)$. Subsequently, the second exponential growth phase also increased, from 3 to 6 days, and the growth rate decreased $\left(2.5 \times 10^{-3} \mathrm{~h}^{-1}\right)$. The final stationary growth phase was reached at $360 \mathrm{~h}$ rather than the $216 \mathrm{~h}$ required in the individual study. The main difference between the two systems is that in the integrated system the P.a. reactor was supplemented with hydrogen sulfide; this compound can affect the cellular growth and biological activity of $P$. aeruginosa.

With respect to waste treatment (Fig. 6), it was observed that at $96 \mathrm{~h}$, i.e. before the supply of hydrogen sulfide, partial elimination of heavy metals in solution was obtained in the P.a. reactor [91\% $\mathrm{Cr}(\mathrm{III}), 48 \% \mathrm{Cu}(\mathrm{II}), 30 \% \mathrm{Mn}(\mathrm{II}), 50 \% \mathrm{Zn}(\mathrm{II})]$. This fact can be attributed to the capacity of $P$. aeruginosa to attract these metals by means of functional groups on their cell wall. This phenomenon was demonstrated in a previous study [34]. The uptake of metals by biomass may be due to one or more of the following processes: ion exchange, physical adsorption, chemical sorption, complexation and microprecipitation [36-38]. $24 \mathrm{~h}$ after the addition of hydrogen sulfide, a notable decrease in the heavy metals in solution was obtained and this could be due to the generation of insoluble compounds. Finally, removal percentages subsequently remained constant with time, meaning that $240 \mathrm{~h}$ was considered the time in which maximum precipitation/biosorption percentages of heavy metals were reached (higher than $99 \%$ for each metal). At that point the D.sp. reactor operation was interrupted and the P.a. reactor was kept working with the purpose of obtaining a higher level of TPH degradation. After 15 days of running, i.e. the same time employed in the individual experiment, $84 \%$ of the petroleum had

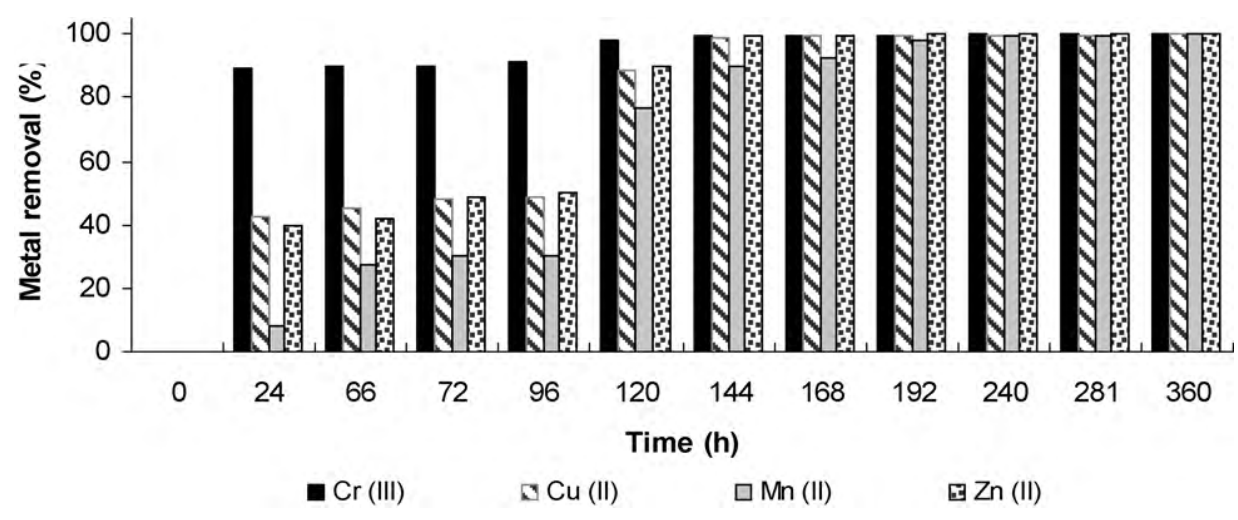

Fig. 6. Removal percentages for $\mathrm{Cr}(\mathrm{III}), \mathrm{Cu}(\mathrm{II}), \mathrm{Mn}(\mathrm{II})$ and $\mathrm{Zn}(\mathrm{II})$ after precipitation-biodegradation integrated process, in the effluent of P.a. reactor. 
been degraded. Analysis by gas chromatography (Fig. 7) showed the total degradation of n-alkane, isoprenoid and naphthalene fractions, and only a proportion of the aromatic hydrocarbons were not degraded. Biodegradation is attributed mainly to the action of $P$. aeruginosa but the possibility of Desulfovibrio $s p$. participating to a lesser extent in this process cannot be ruled out. Sulfate-reducing bacteria are heterotrophic organisms that use organic substrates as carbon and energy sources. These bacteria have the capacity to degrade aliphatic and aromatic hydrocarbons such as benzoates, catechol, indole derivatives and chlorophenols $[39,40]$ and convert them into simpler compounds $\left(\mathrm{CO}_{2}\right)$.

\section{Conclusions}

The combination of the bioreactors with Desulfovibrio $s p$. and $P$. aeruginosa cultures, with the purpose of treating heavy metal/petroleum contaminated media, allows to achieve the total removing of heavy metals in solution and a high degradation of total petroleum hydrocarbons (84\%). These removing percentage are higher those obtained in treatment with bioreactors separately in the same operation time. The integration of precipitation/degradation processes was satisfactory for the overall elimination of heavy metals and petroleum which reached values allows under legislation. The main objective of this study was therefore achieved, and this system could be applied to the treatment of wastes with the defined characteristics. Our research group is currently focused on improving this process with the aim of reducing the operation time and minimizing the effects observed on bacterial activity. In this respect, $P$. aeruginosa are being cultivated in anaerobic conditions to avoid the entry of oxygen into the sulfate-reducing bacteria reactor, which in turn will enable the system to work at a higher rate. This change is based on the fact that bacteria belonging to the genus Pseudomonas are heterotrophic and are able to grow under anaerobic conditions, using nitrates for their respiration. On the other hand, we are also working on the prior adaptation of the strains used to grow in the presence of heavy metals and petroleum in an effort to obtain strains with high resistance to these contaminants. If these two changes are successfully proved, we could consider the incubation of both strains in a single reactor, which will simplify the process significantly.

\section{Acknowledgement}

This work was supported financially by the Spanish International Cooperation Agency through Project A/3959/05.

\section{References}

[1] R. Iturbe, C. Flores, C. Chávez, A. Ramírez, L.G. Torres, In situ flushing of contaminated soils from a refinery: organic compounds and metal removals, Rem. J. 14 (2004) 141-152.

[2] N. Pérez, A. Marañón, R.C. Bermúdez, I. Aguilera, F. Cumbá, A. Abalos, Characterization of wasteswater of Hermanos Díaz refinery, Rev. Cuban. Quím. XVI (2004) 53-60.

[3] J.M. Neff, Polycyclic Aromatic Hydrocarbons in the Aquatic Environments, Applied Science Publishers, London, 1979.

[4] W.T. Piver, F.T. Lindstrom, Waste disposal technologies for polychlorinates biphenyls, Environ. Health Perspect. 59 (1985) 163.

[5] A. Luptakova, M. Kusnierova, Sulfate-reducing bacteria in biohydrometallurgy, in: V International Conference Metallurgy, Refractories and Environment, Vysoke Tatry, 2002, pp. 199-204.

[6] V.S. Steed, M.T. Suidan, M. Gupta, T. Miyahara, C.M. Acheson, G.D. Sayles, Development of a sulfate-reducing biological process to remove heavy metals from acid mine drainage, Water Environ. Res. 72 (2000) 530-535.

[7] J.R. Lloyd, A.N. Mabbet, D.R. Williams, L.E. Macaskie, Metal reduction by sulfate reducing bacteria: physiological diversity and metal specificity, Hydrometallurgy 59 (2001) 327-337.

[8] J.R. Lloyd, Microbial reduction of metals and radionuclides, FEMS Microbiol. Rev. 27 (2003) 411-425.
[9] G.M. Gadd, Microbial influence on metal mobility and application for bioremediation, Geoderma 122 (2004) 109-119.

[10] J. Boonstra, R. van Lier, G. Janssen, H. Dijkman, C.J.N. Buisman, Biological treatment of acid mine drainage, in: R. Amils, A. Ballester (Eds.), Biohydrometallurgy and the Environment Toward the Mining of the 21st Century, Proceedings of the International Biohydrometallurgy Symposium, Madrid, 1999, pp. 559-567.

[11] S. Mossa, M. Nemati, S.T.L. Harrison, A kinetic study on anaerobic reduction of sulfate. Part I. Effect of sulfate concentration, Chem. Eng. Sci. 57 (2002) 2773-2780.

[12] C.N. Hass, C. Polprasert, Biological sulfide prestripping for metal and COD removal, Water Environ. Res. 65 (1993) 645-649.

[13] D.H. Dvorak, R.S. Hedin, H.M. Edembora, P.E. McIntire, Treatment of metalcontaminated water using bacterial sulfate reduction: result from pilot scale reactors, Biotechnol. Bioeng. 40 (1992) 609-616.

[14] P. Elliott, S. Ragusa, D. Catcheside, Growth of sulfate reducing bacteria under acidic conditions in an upflow anaerobic bioreactor as a treatment system for acid mine drainage, Water Res. 32 (1998) 3724-3730.

[15] G.H. Farmer, D.M. Updegraff, P.M. Radehaus, E.R. Bates, Metal removal and sulfate reduction in low-sulfate mine drainage, in: R.E. Hinchee, I. Jeffrey, R. Burris (Eds.), Bioremediation of Inorganics, vol. 10, 1995, pp. 17-24.

[16] R.W. Hammack, H. Dijkman, The application of bacterial sulfate reduction treatment to severely contaminate mine waters: results of three years of pilot plant testing, in: S.K. Young, D.B. Dreisinger, R.P. Hacki, D.G. Dixon (Eds.), Proceedings of Copper99-International Conference Hydrometallurgy of Copper IV, Warrandale, PA, 1999, pp. 97-111.

[17] D.B. Nedwell, P.J. Reynolds, Treatment of landfill leached by methanogenic and sulfate-reducing digestion, Water Res. 30 (1956) 21-28.

[18] X. Max, Y. Hua, $\mathrm{Cd}^{2+}$ removal from wastewaters by sulfate-reducing bacteria with an anaerobic fluidized bed reactor, J. Environ Sci. 9 (1997) 366-371.

[19] A.M. Solanas, R. Pares, J.M. Bayona, J. Albaiges, Degradation of aromatic petroleum hydrocarbons by pure microbial cultures, Chemosphere 13 (1984) 593-601.

[20] M. Viñas, M. Grifoll, J. Sabate, A.M. Solanas, Biodegradation of a crude oil by three microbial consortia of different origins and metabolic capabilities, J. Ind. Microbiol. Biotechnol. 28 (2002) 252-260.

[21] A.L. Balcht, R.P.Smith, Pseudomonas aeruginosa: Infections and Treatment, Marcel Dekker Inc., New York, 1994.

[22] K.J. Ryan, C.G. Ray, Sherris Medical Microbiology, 4th ed., McGraw Hill, United States, 2004.

[23] R. Pérez, A. Abalos, J.M. Gómez, D. Cantero, Biodegradation of crude oil by Pseudomonas aeruginosa AT18 strain, Rev. Technol. Quím. XXXI (2006) 70-77.

[24] M.R. Bruins, S. Kapil, F.W. Oehme, Microbial resistance to metals in the environment, Ecotoxicol. Environ. Safe. 45 (2000) 198-207.

[25] J.R. Lloyd, Bioremediation of metals: the application of microorganisms that make and break metals, Microbiol. Today 29 (2002) 67-69.

[26] A. Raab, J. Feldmann, Microbial transformation of metals and metalloids, Sci. Prog. 86 (2003) 179-202.

[27] A. Linos, R. Reichelt, U. Keller, A. Steinbuchel, A gram negative bacterium, identified as Pseudomonas aeruginosa AL98, is a potent degrader of natural rubber and synthetic cis-1,4-polyisoprene, FEMS Microbiol. Lett. 182 (2000) 155-161.

[28] R. Pérez, M. Camacho, J.M. Gómez, A. Ábalos, M. Viñas, D. Cantero, Isolation and selection of one bacteria strain petroleum-degrading from soil contaminate with petroleum, Rev. Cenic. Biol. 39 (2008) 44-51.

[29] J.R. Postgate, The Sulfate-reducing Bacteria, 2nd ed., Cambridge University Press, Cambridge, 1984.

[30] APHA, AWWA, WEF, Standard Methods for the Examination of Water \& Wastewater, 21st ed., DC American Public Health Association, Washington, 2005.

[31] M. Viñas, Bioremediation of soil contaminated by hydrocarbons: microbiology caracterization, chemical and ecotoxicolgy, Ph.D. Department of Microbiology, University of Barcelona, Spain, 2005.

[32] G. Cabrera, R. Pérez, J.M. Gómez, A. Abalos, D. Cantero, Toxic effects of dissolved heavy metals on Desulfovibrio vulgaris and Desulfovibrio sp. strains, J. Hazard. Mater. A135 (2006) 40-46.

[33] B. Christensen, M. Leaake, T. Lien, Treatment of acid mine water by sulfatereducing bacteria: results from a bench scale experiment, Water Res. 30 (1996) 1617-1624.

[34] R.M. Pérez, A. Abalos, J.M. Gómez, D. Cantero, Biosorption of chromium, copper, manganese and zinc by Pseudomonas aeruginosa AT18 isolated from a site contaminated with petroleum, Bioresour. Technol. 100 (2009) 1533-1538.

[35] A. Morán, N. Olivera, M. Commendatore, J. Esteves, F. Siñeriz, Enhancement of hydrocarbon waste biodegradation by addition of a biosurfactant from Bacillus subtilis 09, Biodegradation 11 (2000) 65-71.

[36] H.C. Kasan, The role of waste activated sludge and bacteria in metal-ion removal from solution, CRC Rev. Env. Sci. Technol. 23 (1993) 79-117.

[37] J.S. Chang, R. Law, C.C. Chang, Biosorption of lead copper and cadmium by biomass of Pseudomonas aeruginosa PU21, Water Res. 31 (1997) 1651-1658.

[38] H. Hussein, S. Farag, K. Kandil, H. Moawad, Tolerance and uptake of heavy metals by Pseudomonas, Process Biochem. 40 (2005) 955-961.

[39] F. Widdel, F. Musat, K. Knittel, A. Galushko, Anaerobic degradation of hydrocarbons with sulphate as electron acceptor, in: L. Barton, W.A. Hamilton (Eds.) Sulphate Reducing Bacteria: Environmental and Engineering Systems, Cambridge University Press, United Kingdom, 2007, pp. 265-304.

[40] E.A. Paul, F.E. Clark, Soil Microbiology and Biochemistry, Academic Press, Inc. San Diego, CA, 1996 